\title{
Does Foreign Direct Investment Affect Employment in Guinea: Empirical Assessment
}

\author{
Oumar Keita ${ }^{1} \&$ Yu Baorong ${ }^{1}$ \\ ${ }^{1}$ School of Insurance and Economics, University of International Business and Economics, Beijing, China \\ Correspondence: Oumar Keita, School of Insurance and Economics, University of International Business and \\ Economics, Beijing 100029, China. Tel: +86-185-1447-7352.
}

Received: September 22, 2021

Accepted: October 17, $2021 \quad$ Online Published: December 1, 2021

doi:10.5539/ijef.v13n12p118

URL: https://doi.org/10.5539/ijef.v13n12p118

\begin{abstract}
This study shed light on the extent to which foreign direct investment contribute to employment in Guinea. FDI per GDP net inflows and unemployment rate are adopted as key indicators whereas inflation, trade openness, credit to private sector are control variables.

The empirical evidence is computed through ARDL method and the subsequent findings are established: first, foreign investment negatively and insignificantly affects unemployment in the short run. This result may be linked to the fact that a huge portion of FDI in Guinea is resource seeking type which itself does not generate enough jobs in the affiliate firms. Moreover, the interactions between such kind of investment and local suppliers are very limited, mitigating its effect on employment in the supplier's side. Second, the short term coefficients for inflation and credit to private sector are positive and insignificant, contradicting a popular macroeconomic theory known as Phillips curve.

Overall, government should promote investments that can have transformative effect on domestic economy through linkages and spillovers. Furthermore, special emphasis must be put on human capital (education and healthcare) so that Guinean youth could be more competitive and capable to seize job opportunities offered both by foreign multinationals and local firms.
\end{abstract}

Keywords: FDI, employment, credit to private sector, inflation, trade openness

\section{Introduction}

Decades ago, unprecedented surge in global foreign direct investment (FDI) has engendered perceptible modifications in labor markets for both industrialized and developing countries. Predominant theoretical assumptions presume foreign investment to promote capital accumulation, convey technologies and new managerial practices to affiliate firms and industries, therefore influencing both the supply and demand for labor and consequently employment, wage inequality, productivity and labor force composition. Several empirical studies have investigated these effects pointing expressly the recipient countries. Since the existing structure of labor force is relatively disparate in developed and emerging economies, it becomes crucial to determine what kind of impacts on labor market to be assessed.

From this perspective, we can differentiate direct effects on target firms and spillover effects. This distinction is necessary for the following reason. While direct impacts of FDI on target corporations are mostly the result of foreign investors decision, spillover effects on local firms are external matter that may warrant public policies towards foreign capital enticement, whether the externality is positive or harmful.

We found a large consensus in the literature in terms of the associated impacts of foreign investment on employment. In this section, we only explore the heterogeneous influence of FDI on labor market in three different categories of domestic firms: foreign owned local corporations, local enterprises supplying transnationals and local firms competing with multinational branches.

\section{a- On affiliate firms}

Firm level evidence asserts that inward foreign direct investment generate comfortable jobs through higher wages compared to their local counterparts. This wage competitiveness may strengthen labor productivity in developing economies. 


\section{b- On Suppliers}

The employment engendered via multinationals-suppliers interaction depends on the robustness of upstream linkages. In developing countries such as Guinea, this upstream relationship seems to be very limited since foreign investors primarily rely on importations, as showed by their soaring portions of importations likened to local counterparts.

\section{c- On Competitors}

A recent comprehensive survey (World bank) from more than hundred emerging countries displays that FDI's impact on local competitors' employment tend to be null, sometimes moderately negative. If labor demand is driven by productive activities, then the null influence or negative effect on output may convey analogous outcomes on employment.

Within this study, we try to elucidate the long and short term association among foreign direct investment and employment in Guinea. This empirical assessment is even more relevant for Guinea since a large proportion of youth is unemployed, allowing civil society and scholars to question the "job generation capacity" of FDI in the Guinean context. From the government side, one may wonder about the effectiveness of foreign capital enticement policies to alleviate endemic unemployment in the country.

The remaining part of the article is arranged as follow: literature is reviewed in subsection 2, data and variables are portrayed in subsection 3, empirical findings are displayed in subsection 4 while conclusions are exhibited in subsection 5.

\section{Literature Review}

Most empirical studies in the literature that assess the impacts of inward foreign investment on recipient economies commonly agree on the fact that FDI convey new managerial practices, refined technologies, scale-up production capabilities, therefore generate positive effects on employment. However, within this section we only explore the literature related to the heterogeneous influence of inward investment on foreign owned local corporations, local enterprises supplying transnationals and then local firms competing with multinational subsidiaries.

Karlsson et al. (2009) from an empirical analysis on China manufacturing corporations, found that multinationals subsidiaries experience substantial increase in employment likened to their local counterparts in the similar industry. This fact can be an outcome of firm specific features such as high productivity, capital intensity also the access to export markets.

Gong and Miaoli (2006) employing similar approach discovered that multinationals owning former state corporations engenders great employment rate in the post-acquisition period. Such firms experience $5.5 \%$ in $75^{\text {th }}$ percentile and $12.5 \%$ in $90^{\text {th }}$ percentile average increase in employment.

Jenkins (2006) investigated foreign investment induced impacts on labor market within secondary sector in Vietnam and noticed a limited job generation effect on upstream industries owing to inadequate local interactions.

Working on a developing country like Ghana where the level of unemployment is relatively high, Abor and Harvey (2008) concluded that FDI could be an impetus for GDP growth which in turn generate some large scale employment opportunities. Craigwell (2006) found the same conclusion on Caribbean region.

Brincikova and Darmo (2014) examined the case of V4 countries (Czech Republic, Hungary, Poland \& Slovakia) and concluded that there was no significant impact of FDI inflows on unemployment, but GDP growth was influenced.

Reyes (2017) adopting a comprehensive dataset (World Bank) from more than hundred developing nations, showed that inward investment in some specific sectors might not significantly affect the average growth in job generation.

Blalock and Gertler (2008) looking at Indonesia manufacturing companies, posit that local firms that have common suppliers with foreign subsidiaries experience significant growth in production which increase jobs opportunities.

Overall, literature scrutinizing the interaction among inward foreign investment and employment is still equivocal from both empirical and theoretical viewpoints. Research papers using diverse econometric frameworks obtained assorted outcomes. To our awareness, such original study has not been exclusively performed in Guinea. 


\section{Methodology}

\subsection{Data Description}

To shed light on the extent to which foreign direct investment contribute to employment in Guinea, this empirical assessment selects per GDP FDI net inflows and unemployment rate as key variables. Both are annual basis time series data over the period 1990-2017. All the dependent, independent and control variables are extracted from World Bank data set.

\section{Foreign Direct Investment Variable}

Foreign direct investment embodies aggregate inward financial resources (brownfield, greenfield, reinvested earnings, equity capital). Within this study, we employ FDI per GDP indicator which is the ratio of inward foreign investment over GDP.

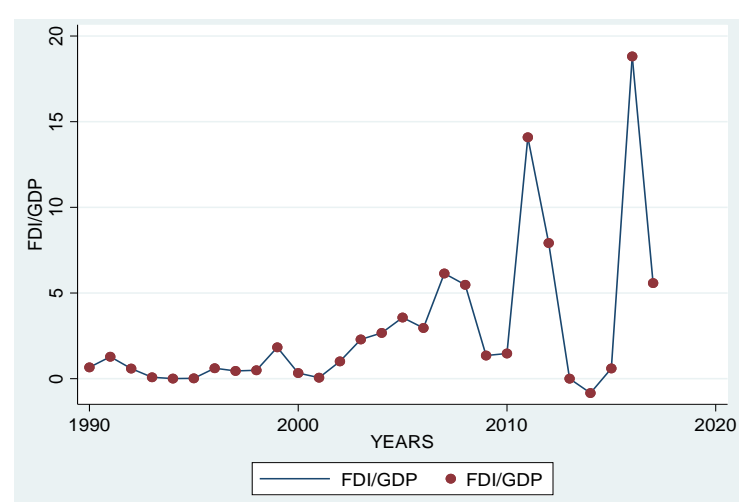

Figure 1. Foreign direct investment per GDP net inflows

\section{Employment Variable}

Unemployment rate reflects the portion of labor force that is qualified, available and looking for employment but without job. It is one of the main indicator governments refer to assess the health of an economy.

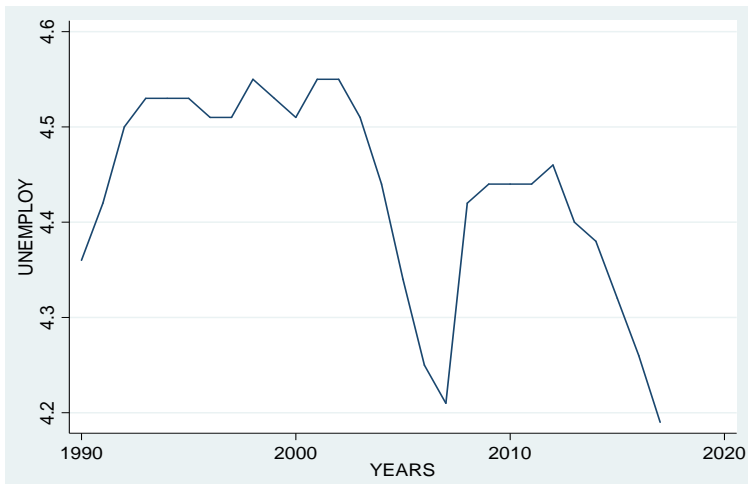

Figure 2. Unemployment rate

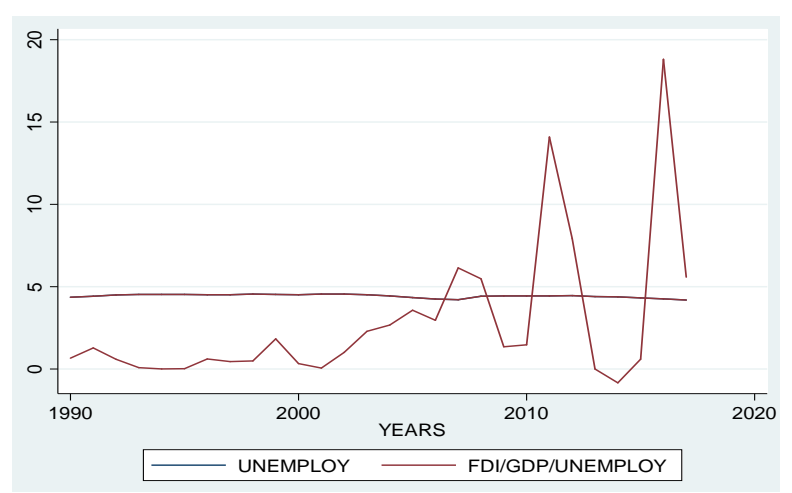

Figure 3. FDI per GDP net inflows and unemployment rate range plot 


\section{Control Variables}

- Trade openness highlights the extent to which Guinean economy is opened to global trade. It's the annual value of recorded exports and imports from the country.

- Inflation refers to the stability of the average price (CPI basis). It is recognized to be suitable proxy for macroeconomic stability.

- Credit to private sector represents loans, securities, grants and other facilities that financial institutions offered to private businesses.

\subsection{Models Specification}

To capture the adjusted dynamics among inward foreign investment and employment, the commonly adopted framework is:

$$
\text { Unemploy }_{\mathrm{it}}=\beta_{1}+\beta_{2} F D I_{\mathrm{it}}+\beta_{3} X_{\mathrm{it}}+\varepsilon_{\mathrm{it}}
$$

Where Unemploy $y_{\mathrm{it}}$ refers to unemployment level of nation $i$ at time $t, F D I_{\mathrm{it}}$ is foreign investment net inflows, $X_{\mathrm{it}}$ represents the series of control variables while $\varepsilon_{i t}$ stands for error terms. This measurement method might not apprehend possible adjustment of unemployment rate over time. For this motive, we assess the relationship among the two variables through ARDL framework specified by Pesaran et al (2001).

$$
\begin{gathered}
\Delta \text { Unemploy }_{t}=\mathrm{a}_{0}+\Sigma_{\mathrm{i}=1}^{\mathrm{p}} \mathrm{a}_{1 \mathrm{i}} \text { UUnemploy }{ }_{t-i}+\sum_{\mathrm{i}=1}^{\mathrm{q}} \mathrm{a}_{2 \mathrm{i}} \Delta F D I_{t-1}+\sum_{\mathrm{i}=1}^{\mathrm{q}} \mathrm{a}_{3 \mathrm{i}} \text { Inflation }_{-\mathrm{i}}+\sum_{\mathrm{i}=1}^{\mathrm{q}} \mathrm{a}_{4 \mathrm{i}} \text { SOPenness }_{\mathrm{t}-1}+ \\
\sum_{\mathrm{i}=1}^{\mathrm{q}} \mathrm{a}_{5 \mathrm{i}} \Delta \text { Credit }_{\mathrm{t}-\mathrm{i}}+\lambda E C T_{\mathrm{t}-1}+\mathrm{e}_{\mathrm{t}}
\end{gathered}
$$

- $\quad \lambda=\left(1-\Sigma^{\mathrm{p}}{ }_{\mathrm{i}=1} \delta_{\mathrm{i}}\right)$, Speed of adjustment parameter with a negative sign

- $\quad \mathrm{ECT}=\left(\Delta\right.$ Unemploy $\left._{\mathrm{t}-\mathrm{i}}-\mathbf{\theta X}_{\mathrm{t}}\right)$, the error correction term is the derived residuals from the regression of the long term equation

- $\quad \boldsymbol{\theta}=\Sigma_{\mathrm{i}=0}^{\mathrm{q}} \beta_{\mathrm{i}} / \alpha$, is the long term parameter

$\mathrm{a}_{1 \mathrm{i}}, \mathrm{a}_{2 \mathrm{i}}, \mathrm{a}_{3 \mathrm{i}}, \mathrm{a}_{4 \mathrm{i}}$ and $\mathrm{a}_{5 \mathrm{i}}$ are the short term dynamic coefficients of the model's adjustment long term equilibrium.

Whether the time series are I (0) or I (1) or I (0) and I (1), ARDL by Pesaran et al. (2001) enables us to perfectly seize the interaction among our targeted variables.

\section{Empirical Results}

Table 1. Summary statistics

\begin{tabular}{cccccc}
\hline & FDI/GDP & Unemployment & Credit & Inflation & Trade Openness \\
\hline Observations & 28 & 28 & 28 & 28 & 28 \\
Maximum & 18.81 & 4.55 & 10.9577 & 34.69 & 112.94 \\
Minimum & -0.84 & 4.19 & 2.6598 & 1.93 & 42.41 \\
Mean & 2.839607 & 4.431429 & 5.136586 & 12.42286 & 64.97464 \\
Stand. Dev. & 4.45062 & 0.1073145 & 2.26786 & 8.882227 & 18.29165 \\
Variance & 19.80802 & 0.0115164 & 5.143187 & 78.89396 & 334.5846 \\
Skewness & 2.327381 & -0.8392702 & 1.240948 & 0.9038934 & 1.06703 \\
Kurtosis & 8.094086 & 2.650559 & 3.334857 & 2.970038 & 3.751382 \\
\hline
\end{tabular}

The summary statistics of per GDP FDI inflows, unemployment rate, credit to private sector, inflation and trade openness are presented in table 1. The following trends are noticeable: first, FDI flows have experience a steady growth from 2010 up to date. This can be explained by major mining projects sponsored by china multinationals, especially in bauxite industry. Second, Unemployment rate has known a slight decline over the same period, raising interests to test the correlation between the two variables.

Table 2. Correlation matrix

\begin{tabular}{ccccc}
\hline & FDI/GDP & Unemployment & Credit & Inflation \\
\hline FDI/GDP & 1.0000 & & & \\
Unemployment & -0.4531 & 1.0000 & & \\
Credit & 0.2255 & -0.3188 & 1.0000 & 1.0000 \\
Inflation & 0.2475 & -0.5245 & -0.1945 & 0.2463 \\
Trade Openness & 0.6815 & -0.7452 & 0.5683 & 1.0000 \\
\hline
\end{tabular}


Table 2 reports the correlation between the key variables. Results are obvious about the negative correlation among unemployment, FDI per GDP, credit to private sector, inflation and trade openness. Moreover, correlation coefficients are lower than $75 \%$ meaning that our variables are not multi-collinear.

\subsection{Unit Root Test}

Unit root is a stochastic trend that can alter statistical inference involving time series analysis. To determine the appropriate econometric approach that seize the pivotal relationship among our main indicators, we employ both Augmented Dickey Fuller technique and Phillips Perron framework to test the stationarity of our time series indicators. The outcomes are summarized in table 3. From ADF and PP test results, it is obvious that per GDP FDI is stationary at level whereas Unemployment, Credit to private sector, inflation and trade openness are stationary at first difference.

Table 3. Augmented Dickey Fuller (ADF) and Phillips Perron (PP) unit root tests

\begin{tabular}{ccccc}
\hline Variables & \multicolumn{2}{c}{ ADF test } & PP test \\
\cline { 2 - 5 } & Level & First Difference & $-3.867^{* * *}$ \\
\hline FDI/GDP & $-3.531^{* * *}$ & & -1.262 & First Difference \\
Unemployment & -1.446 & $-3.180^{* * *}$ & -1.003 & $-3.426^{* * *}$ \\
Credit & -0.691 & $-3.914^{* * *}$ & -2.636 & $-6.063^{* * *}$ \\
Inflation & -2.208 & $-3.305^{* * *}$ & 0.222 & $-5.659^{* * *}$ \\
Openness & 0.182 & $-3.282^{* * *}$ & $-5.134^{* * *}$ \\
\hline
\end{tabular}

Since the unit root tests evidently showed that our time series variables entirely combined I (0) and I (1). This enables us to proceed the second step which is the Bounds test procedure.

Table 4. Lag selection criteria

\begin{tabular}{ccccccccc}
\hline Lag & LL & LR & df & $\mathrm{p}$ & FPE & AIC & HQIC & SBIC \\
\hline 0 & -250.236 & - & - & - & 507.607 & 20.4189 & 20.4865 & $20.6627^{*}$ \\
1 & -229.078 & 42.316 & 25 & 0.017 & 723.852 & 20.7262 & 21.1319 & 22.1889 \\
2 & -187.244 & 83.668 & 25 & 0.000 & 247.751 & 19.3795 & 20.1232 & 22.061 \\
3 & -140.994 & $92.499^{*}$ & 25 & 0.000 & $106.902^{*}$ & $17.6796^{*}$ & $18.7614^{*}$ & 21.58 \\
\hline
\end{tabular}

Endogenous: GDP Growth rate, FDI/GDP, Inflation, Credit to private sector, trade Openness.

Exogenous:_Cons.

$\begin{array}{cccccc}\text { E (lags) }[1,5]=\text { Unemployment } & \text { FDI/GDP } & \text { Credit } & \text { Inflation } & \text { Openness } \\ \mathrm{rl} & 3 & 3 & 3 & 2 & 3\end{array}$

\subsection{Outcomes of Bounds Test Procedure}

Table 5. Pesaran / Shin / Smith (2001) ARDL Bounds Test

Ho: No levels relationship

$\mathrm{F}=0.861$

$\mathrm{t}=-0.375$

\begin{tabular}{|c|c|c|c|c|}
\hline \multicolumn{5}{|c|}{ Critical Values $(0.1-0.01), \quad$ F-statistic } \\
\hline & [I_0] & [I_0] & [I_0] & [I_0] \\
\hline & [I_1] & [I_1] & [I_1] & [I_1] \\
\hline & L_1 & L_05 & L_025 & L_01 \\
\hline & L_1 & L_05 & L_025 & L_01 \\
\hline \multirow[t]{8}{*}{ K_4 } & 2.45 & 2.86 & 3.25 & 3.74 \\
\hline & 3.52 & 4.01 & 4.49 & 5.06 \\
\hline & \multicolumn{4}{|c|}{ Accept if $\mathrm{F}<$ critical value for $\mathrm{I}(0)$ regressors; Reject if $\mathrm{F}>$ critical value for $\mathrm{I}(1)$ regressors } \\
\hline & \multicolumn{4}{|c|}{ Critical Values $(0.1-0.01), \quad$ t-statistic } \\
\hline & [I_0] & [I_0] & [I_0] & [I_0] \\
\hline & [I_1] & [I_1] & [I_1] & [I_1] \\
\hline & L_1 & L_05 & L_025 & L_01 \\
\hline & L_1 & L_05 & L_025 & L_01 \\
\hline \multirow[t]{2}{*}{ K_4 } & -2.57 & -2.86 & -3.13 & -3.43 \\
\hline & -3.66 & -3.99 & -4.26 & -4.60 \\
\hline
\end{tabular}


Findings from the Bounds test framework exhibited that our subtracted F-statistic is smaller than the critical value for the lower bound I (0). Therefore, we can deny the existence of co-integration, denoting the absence of long term connection among the variables. Under this condition, we can only perform the ARDL framework to apprehend the short term interaction.

\subsection{Results of Auto Regressive Distributed Lag Model}

Table 6. The ARDL model

\begin{tabular}{ccccccc}
\hline Unemployment & Coef & Std. Err. & $\mathrm{t}$ & $\mathrm{P}>[\mathrm{t}]$ & \multicolumn{2}{c}{$[95 \%$ Conf. Interval] } \\
\hline Unemployment & & & & & & \\
L1. & 0.7710111 & 0.4225586 & 1.82 & 0.118 & -0.2629524 & 1.804975 \\
L2. & -0.8165326 & 0.2590892 & -3.15 & 0.020 & -1.450501 & -0.1825641 \\
L3. & 0.8188098 & 0.3584121 & 2.28 & 0.062 & -0.058193 & 1.695813 \\
FDI/GDP & & & & & & \\
-- & -0.037745 & 0.046112 & -0.82 & 0.444 & -0.0150577 & 0.0075086 \\
L1. & -0.035092 & 0.043528 & -0.81 & 0.451 & -0.0141602 & 0.0071418 \\
L2. & 0.041365 & 0.035215 & 1.17 & 0.285 & -0.0044804 & 0.0127534 \\
L3. & -0.059318 & 0.058746 & -1.01 & 0.352 & -0.0203064 & 0.0084427 \\
Credit & & & & & \\
-- & 0.032526 & 0.0140257 & 0.23 & 0.824 & -0.0310671 & 0.0375723 \\
L1. & 0.059112 & 0.013253 & 0.45 & 0.671 & -0.0265177 & 0.0383401 \\
L2. & -0.066388 & 0.0180655 & -3.67 & 0.010 & -0.1105928 & -0.0221833 \\
L3. & 0.0211715 & 0.021068 & 1.00 & 0.354 & -0.03038 & 0.0727231 \\
Inflation & & & & & & 0.076906 \\
-- & 0.027994 & 0.01999 & 1.40 & 0.211 & -0.020919 & -0.05653 \\
L1. & -0.0121879 & 0.026707 & -4.56 & 0.004 & -0.0187227 & 0.0146803 \\
L2. & 0.0505 & 0.039357 & 1.28 & 0.247 & -0.045804 & 0.095222 \\
Openness & & & & & & 0.041967 \\
-- & 0.044923 & 0.020556 & 2.19 & 0.072 & -0.05376 & 0.047808 \\
L1. & -0.05366 & 0.019344 & -0.28 & 0.791 & -0.052698 & 0.0100975 \\
L2. & -0.06705 & 0.022278 & -0.30 & 0.774 & -0.061218 & -0.024961 \\
L3. & 0.038007 & 0.025734 & 1.48 & 0.190 & -0.029927 & 0.0151997 \\
Cons & -0.073638 & 0.092212 & -0.80 & 0.455 & &
\end{tabular}

$\mathrm{F}(18,6)=3.65 ;$ Prob $>\mathrm{F}=0.0580 ; \mathrm{R}-\mathrm{Sq}=0.9164 ;$ Adj R-Sq $=0.6654 ;$ Root MSE $=0.0352$.

Table 6 exhaustively displays the interactions among per GDP FDI inflows, unemployment rate, credit to private sector, inflation and trade openness. The coefficients show that foreign investment negatively affect unemployment in the short term but not significantly. This finding concurred with the assorted results that characterized the preponderant empirical literature. Most of these studies posit that FDI and employment nexus depends on the features and specificities of the recipient countries. Within the Guinean context, it is interesting to assess our outcome from the aforementioned perspective. First, a large fraction of FDI in Guinea is resource seeking type which itself does not generate enough jobs in the affiliate firms. Second, the interaction between such kind of investment and local suppliers is very limited, mitigating its effect on employment in the supplier's side.

With inflation and credit to private sector, the short term coefficients are positive and insignificant. This finding is contradicting a popular macroeconomic theory known as Phillips curve. Trade openness variable is negatively and insignificantly associated with unemployment.

\subsection{Robustness Check}

To ensure the reliability of our empirical findings, we performed the following diagnosis tests:

Durbin-Watson d-statistic test: $(19,25)=2.00$

The Durbin-Watson test result (2.00) endorses the fact that our empirical design is not presenting serial auto-correlation problem. 
Table 7. Breusch-Godfrey LM test

\begin{tabular}{cccc}
\hline Lags $(\mathrm{p})$ & Chi2 & df & Prob > chi2 \\
\hline 3 & 3.079 & 3 & 0.3796 \\
\hline
\end{tabular}

Ho: no serial correlation.

The Breusch-Godfrey outcomes Prob $>$ chi2 $=(0.3796)$ totally agreed with Durbin-Watson test result. The computed value (0.3796) is higher than 5 per cent, confirming the aforementioned inference.

Table 8. White's test

\begin{tabular}{cccc}
\hline Lags $(\mathrm{p})$ & Chi2 $(24)$ & df & Prob > chi2 \\
\hline 3 & 25.00 & 3 & 0.4058 \\
\hline
\end{tabular}

The White's test computed value Prob $>$ chi2 $=(0.4058)$ is greater than 5 per cent, telling that our empirical framework is not heteroskedastic.

Table 9. Cameron \& Trivedi’s decomposition of IM-test

\begin{tabular}{cccc}
\hline Source & Heteroskedasticity & Skewness & Kurtosis \\
\hline Chi2 & 25.00 & 13.58 & 1.24 \\
Df & 24 & 18 & 1 \\
P & 0.4058 & 0.7562 & 0.2660 \\
Total & 39.82 & 43 & 0.6102 \\
\hline
\end{tabular}

The skewness and Kurtosis calculated values [Prob > Chi2 higher than 5 per cent] from Cameron \& Trivedi's diagnosis display that residuals are normally distributed.

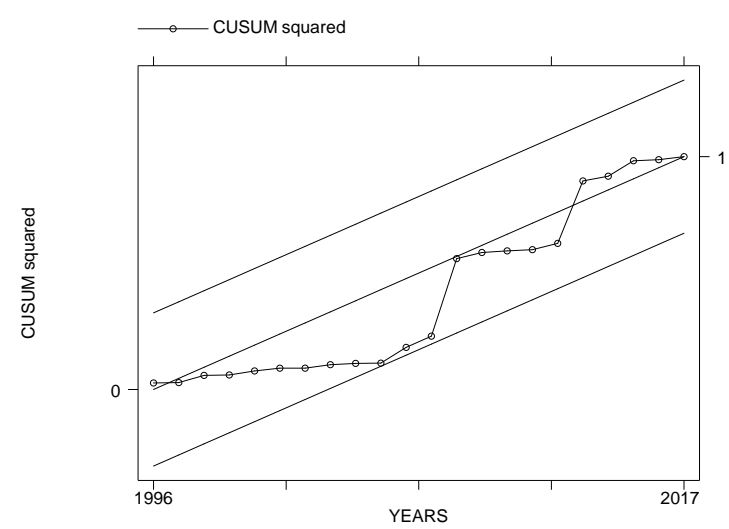

Figure 4. CUSUM Squared test

The Cusum squared test obviously exhibits that our empirical framework is stable enough. Hence we employed the relevant model.

\section{Conclusion}

In developing countries, foreign direct investment is considered to be a main vehicle that can compensate the gap between local savings and the pressing needs in terms of financial resources. Many scholars have then focused their attention on the impact of FDI on various macro variables: capital accumulation (Jude \& Silaghi, 2016); welfare (Gohou \& Soumaré, 2012); technology transfer (Kim, 2008); inequality (Wu \& Hsu, 2012); competitiveness (Zhang, 2014); economic growth (Malikane \& Chitambara, 2017). Surprisingly, little consideration was paid to the impact of FDI on employment in Guinea.

To enrich the literature, this study as a pioneer tests the extent to which foreign direct investment inflows contribute to employment covering the period 1990-2017. FDI per GDP and unemployment rate are correspondingly adopted as FDI and employment indicators.

The ARDL framework supports the following outcomes. First, foreign investment negatively and insignificantly 
affects unemployment in the short run. This finding resulted from the fact that a huge portion of FDI in Guinea is resource seeking type which itself does not generate enough jobs in the affiliate firms. Moreover, the interaction between such kind of investment and local suppliers is very limited, mitigating its effect on employment in the supplier's side. Second, the short term coefficients for inflation and credit to private sector are positive and insignificant, contradicting a popular macroeconomic theory known as Phillips curve.

Even though the empirical outcomes endorse the statement that foreign investment positively affects employment in Guinea but coefficients are not significant enough. This enables us to formulate further recommendations. Primary, government should not only rely on foreign direct investment to mitigate unemployment in Guinea. Additional efforts are needed to mobilize more internal revenues in order to support other job generating sectors such as agriculture and services. Furthermore, authorities should also promote investments that may have transformative effect on domestic economy through linkages and spillovers. Manufacturing industries must be preferred instead of natural resources seeking capital. Finally, special emphasis must be put on human capital (education and healthcare) so that Guinean youth could be more competitive and capable to seize job opportunities offered by foreign multinationals and local firms.

\section{References}

Aitken, B. J., \& Harrison, A. E. (1999). Do Domestic Firms Benefit from Direct Foreign Investment? Evidence from Venezuela. American Economic Review, 89(3), 605-618. https://doi.org/10.1257/aer.89.3.605

Aitken, B., Harrison, A., \& Lipsey, R. E. (1996). Wages and Foreign Ownership: A Comparative Study of Mexico, Venezuela and the United States. Journal of International Economics, 345-371. https://doi.org/10.1016/0022-1996(95)01410-1

Alfaro, L. (2016). Gains from Foreign Direct Investment: Macro and Micro Approaches. The World Bank Economic Review, 30(Supplement_1). https://doi.org/10.1093/wber/lhw007

Amoranto, G., Brooks, D. H., \& Chun, N. (2010). Services Liberalization and Wage Inequality in the Philippines. ADB Economics Working Paper Series No. 239. https://doi.org/10.2139/ssrn.1761698

Arnold, J. M., Javorcik, B. S., \& Mattoo, A. (2011). Does services liberalization benefit manufacturing firms? Evidence from the Czech Republic. Journal of International Economics, 85(1), 136-146. https://doi.org/10.1016/j.jinteco.2011.05.002

Arnold, J. M., Javorcik, B., Lipscomb, M., \& Mattoo, A. (2014). Services Reform and Manufacturing Performance: Evidence from India. The Economic Journal, 126(590), 1-39. https://doi.org/10.1111/ecoj.12206

Barry, F., Görg, H., \& Strobl, E. (2005). Foreign direct investment and wages in domestic firms in Ireland: Productivity spillovers versus labor-market crowding out. International Journal of Economics and Business, 67-84. https://doi.org/10.1080/1357151042000323102

Belderbos, R., Capannelli, G., \& Fukao, K. (2001). Backward vertical linkages of foreign manufacturing affiliates: Evidence from Japanese multinationals. World Development, 29(1), 189-208. https://doi.org/10.1016/S0305-750X(00)00086-3

Blalock, G., \& Gertler, P. (2008). Welfare Gains from Foreign Direct Investment through Technology Transfer to Local Suppliers. Journal of International Economics, 74, 402-421. https://doi.org/10.1016/j.jinteco.2007.05.011

Blomstrom, M., Lipsey, R., \& Zejan, M. (1994). What explains developing country growth? NBER Working Paper No. 4132. Retrieved from http://www.nber.org/papers/w4132

Bloom, N., \& Van Reenen, J. (2010). Why do management practices differ across firms and countries? Journal of Economic Perspectives, 24(1), 203-24. https://doi.org/10.1257/jep.24.1.203

Blyde, J., Kugler, M., \& Stein, E. (2005). Exporting vs. Local Sourcing by Multinational Subsidiaries: Which Determines Foreign Direct Investment Spillovers? mimeo.

\section{Copyrights}

Copyright for this article is retained by the author(s), with first publication rights granted to the journal.

This is an open-access article distributed under the terms and conditions of the Creative Commons Attribution license (http://creativecommons.org/licenses/by/4.0/). 